\title{
Anti-Adipogenic Polyphenols of Water Shield Suppress TNF- $\alpha$-Induced Cell Damage and Enhance Expression of HAS2 and HAPB2 in Adiponectin- Treated Dermal Fibroblasts
}

Hiroshi Shimoda $^{1 *}$, Seikou Nakamura ${ }^{2}$, Shoketsu Hitoe ${ }^{1}$, Shuko Terazawa ${ }^{1}$, Junji Tanaka ${ }^{1}$, Takahiro Matsumoto ${ }^{2}$ and Hisashi Matsuda ${ }^{2}$

${ }^{1}$ Research and Development Division, Oryza Oil \& Fat Chemical Co., Ltd., 1 Numata, Kitagata-cho, Ichinomiya, Japan

${ }^{2}$ Kyoto Pharmaceutical University, 1 Shichono-cho, Misasagi, Yamashina-ku, Kyoto 607-8412, Japan

\begin{abstract}
Water shield (Brasenia schreberi J. F. Gmel) is an aquatic plant cultivated in Northern Japan, from which we have isolated polyphenolic compounds including a novel flavonol glycoside, junsainoside A. Recently, dermal fibroblasts have reported to be affected by adipocytokines from subcutaneous adipocytes. Hence, we evaluated the effects of polyphenolic compounds from water shield on fat accumulation, adipocytokine release and adipocytokine-induced fibroblast status. In differentiated 3T3-L1 adipocytes, ethyl gallate, caffeoyl glucose, hypolaetin 7-O-glucoside, kaempferol and junsainoside A significantly suppressed lipid accumulation at $10 \mu \mathrm{M}$. In addition to these constituents, ferulic acid, kaempferol 3-O-(6"-galloyl) glucoside, quercetin 3-O-(6"-galloyl) glucoside, quercetin 3-O-glucoside and gossypetin suppressed the lipid accumulation in human subcutaneous adipocytes. Ethyl gallate and junsainoside $\mathrm{A}$ also enhanced adiponectin production from subcutaneous adipocytes without induction of TNF- $\alpha$ release. On the other hand, ethyl gallate and quercetin recovered from TNF- $\alpha$-induced fibroblast damage. Moreover, ferulic acid, quercetin and kaempferol enhanced the expression of hyaluronan binding protein 2 and hyaluronan synthase 2 in adiponectintreated fibroblasts. These results suggested that water shield contains various types of polyphenolic compounds with anti-adipogenic activity, some of which protect dermal fibroblasts from TNF- $\alpha$ damage and probably enhance hyaluronan production. It is assumed that polyphenols in water shield maybe suppress subcutaneous fat accumulation and maintain dermal fibroblast and hyaluronan-related status.
\end{abstract}

Keywords: Water shield; Junsainoside A; Adipocyte; TNF- $\alpha$; Adiponectin; Hyaluronan

Abbreviations: TNF: Tumor Necrosis Factor- $\alpha, \beta$; WSE: Water
shield extract, DEPT: Distortionless enhancement by polarization
transfer, HMQC: Heteronuclear multiple quantum coherence
spectroscopy, HMBC: Heteronuclear multiple bond connectivity,
RIPA: Radioimmunoprecipitation assay, HAS: Hyaluronan synthase,
HABP: Hyaluronan binding protein, HRP: Horseradish peroxidase,
D-MEM: Dulbecco's modified essential medium, FCS: Fetal calf serum,
DMSO: Dimethyl sulfoxide, MTT: 3-(4,5-dimethylthiazol-2-yl)-2,5-
diphenyltetrazolium bromide.

\section{Introduction}

Water shield (Brasenia schreberi J. F. Gmel, Cabombaceae) is an aquatic plant that grows in Asia, Australia, Africa and North America. As the surfaces of its leaves and buds are covered with mucus consisting of polysaccharide [1], the texture is similar to gelatine. In Japan, water shield (junsai in Japanese) is cultivated as a vegetable and the young buds are used as a food ingredient. On the other hand, the leaves have been used as stomachic in China; however, the constituents of water shield have not been well studied. Only quercetin 7-O-glucoside and gallic acid have been reported as principal polyphenols [2]. In terms of the biological activity of the extract from water shield, anti-oxidative [2], anti-inflammatory [2] and hypolipidemic activities [3] have been reported. Considering this background, we performed isolation of the constituents of water shield leaves and identified various types of polyphenol including a new flavonol glycoside named junsainoside A.

A number of polyphenols have been reported to suppress visceral fat accumulation in adipocytes. 3T3-L1 preadipocytes [4] and primary cultured visceral adipocytes [5] have been frequently used for the assay. These results indicate the efficacy of polyphenols against obesityrelated insulin resistance, dyslipidemia and arteriosclerosis. However, from the perspective of dermatology, the effect of polyphenols on subcutaneous fat accumulation has not been well studied. Recently, the relationship between subcutaneous adipocytes and dermal fibroblasts has been focused on. Subcutaneous fat exists in the hypodermis and releases adipocytokines including tumor necrosis factor (TNF) - $\alpha$ and adiponectin [6]. TNF- $\alpha$ is also released from dermal inflammatory cells and induces fibroblast apoptosis [7]. On the other hand, adiponectin enhances hyaluronan and collagen production from fibroblasts [8]. Thus, TNF- $\alpha$ and adiponectin affect dermal fibroblasts with negative and positive responses and the balance of these adipocytokines is considered to be crucial to maintain stable dermal conditions. Against the above background, we investigated the effect of water shield extract (WSE) and its constituents on lipid accumulation and adipocytokine release in subcutaneous adipocytes. In addition, the effects of the constituents on fibroblasts treated with adipocytokines were evaluated.

\section{Materials and Methods}

\section{Preparation of WSE}

The leaves of water shield cultivated in Mitane town (Akita prefecture, Japan) were harvested in June 2011. The leaves were airdried and ground. The powdered leaves $(200 \mathrm{~g})$ were then extracted with $30 \mathrm{w} / \mathrm{w} \%$ ethanol $(\mathrm{EtOH}, 6 \mathrm{~kg})$ at $50^{\circ} \mathrm{C}$ for $2 \mathrm{~h}$. The solvent was evaporated to obtain WSE (44.3 g, yield: $22.1 \%$ ). The polyphenol

*Corresponding author: Hiroshi Shimoda, Research \& Development Division Oryza Oil \& Fat Chemical Co., Ltd., 1 Numata, Kitagata-cho, Ichinomiya, Aichi 493-8001, Japan, Tel: +81-586-86-5141; Fax: +81-586-86-6191; E-mail: kaihatsu@mri.biglobe.ne.jp

Received May 29, 2014; Accepted August 18, 2014; Published August 20, 2014

Citation: Shimoda H, Nakamura S, Hitoe S, Terazawa S, Tanaka J, et al. (2014) Anti-Adipogenic Polyphenols of Water Shield Suppress TNF-a-Induced Cell Damage and Enhance Expression of HAS2 and HAPB2 in Adiponectin-Treated Dermal Fibroblasts. Nat Prod Chem Res 2: 146. doi:10.4172/2329-6836.1000146

Copyright: ( $) 2014$ Shimoda $\mathrm{H}$, et al. This is an open-access article distributed under the terms of the Creative Commons Attribution License, which permits unrestricted use, distribution, and reproduction in any medium, provided the original author and source are credited. 
Citation: Shimoda H, Nakamura S, Hitoe S, Terazawa S, Tanaka J, et al. (2014) Anti-Adipogenic Polyphenols of Water Shield Suppress TNF-aInduced Cell Damage and Enhance Expression of HAS2 and HAPB2 in Adiponectin-Treated Dermal Fibroblasts. Nat Prod Chem Res 2: 146. doi:10.4172/2329-6836.1000146

Page 2 of 7

content determined by the Folin-Ciocalteu method was $27.3 \%$ (gallic acid equivalent).

\section{Isolation of the compounds in water shield}

Dried powder of water shield $(870 \mathrm{~g})$ was extracted with $50 \mathrm{w} / \mathrm{w} \%$ $\mathrm{EtOH}(20 \mathrm{~kg})$ at $80^{\circ} \mathrm{C}$ for $3 \mathrm{~h}$. The solvent was evaporated to obtain $50 \% \mathrm{EtOH}$ extract (188 g, yield: $21.6 \%)$. The extract (100 g) was applied to Diaion HP20 (Mitsubishi Chemical Corporation, Tokyo, Japan) column chromatography ( $1 \mathrm{~kg})$. The column was eluted with 10, 30, 70 and $100 \mathrm{v} / \mathrm{v} \%$ methanol $(\mathrm{MeOH})$ sequentially to obtain a $10 \% \mathrm{MeOH}$ fraction $(2.3 \mathrm{~g}), 30 \% \mathrm{MeOH}$ fraction $(14.2 \mathrm{~g}), 70 \% \mathrm{MeOH}$ fraction $(29$ g) and $100 \% \mathrm{MeOH}$ fraction $(4.7 \mathrm{~g})$. The $10 \% \mathrm{MeOH}$ fraction $(2.3 \mathrm{~g})$ was applied to octadecyl silyl (ODS, Fuji Silysia Chemical Ltd., Kasugai, Japan) silica gel column chromatography (50 g, $10 \rightarrow 20 \rightarrow 30 \% \mathrm{MeOH})$ to obtain fractions: fraction (Fr.) $1(0.79 \mathrm{~g})$, Fr. $2(0.75 \mathrm{~g})$ and Fr. 3 $(0.42 \mathrm{~g})$. Fr. $2(0.75 \mathrm{~g})$ was purified by HPLC $\left(\mathrm{C}_{30}\right.$ column (Develosil RPAQUEOUS; Nomura Chemical Co. Ltd., Seto, Japan, $250 \times 20 \mathrm{~mm}$ i.d.), $10 \% \mathrm{MeOH}$ ) to obtain phenylalanine (1, $2 \mathrm{mg}$, yield: $0.002 \%$ from $50 \% \mathrm{EtOH}$ extract). Fr. 3 ( $0.42 \mathrm{~g})$ was separated by HPLC $\left(\mathrm{C}_{30}\right.$ column, $50 \% \mathrm{MeOH})$ to obtain $p$-phenylbenzoic acid (2,2 mg, 0.002\%) [9]. The $70 \% \mathrm{MeOH}$ fraction $(29 \mathrm{~g})$ was applied to ODS column chromatography $(300 \mathrm{~g}, 40 \rightarrow 50 \rightarrow 60 \rightarrow 70 \rightarrow 100 \% \mathrm{MeOH})$ to obtain fractions: Fr. 1 (23.9 g), Fr. 2 (1.4 g), Fr. 3 (1.8 g), Fr. 4 (0.4 g) and Fr. 5 (0.2 g). Fr. 1 (1 g) was purified by HPLC [ODS column (Inertsil preparative ODS; GL Science, Tokyo, Japan, $250 \times 20 \mathrm{~mm}$ i.d., $40 \% \mathrm{MeOH})$ and $\mathrm{C}_{30}$ column $(60 \%$ $\mathrm{MeOH})$ ] to obtain ethyl gallate (3, $3.2 \mathrm{mg}, 0.076 \%)$ [10], ferulic acid (4, $0.6 \mathrm{mg}, 0.014 \%)$ and caffeoyl glucose $(5,1 \mathrm{mg}, 0.024 \%)$ [11]. Fr. 2 (1.4 g) was purified by HPLC (ODS column $(50 \% \mathrm{MeOH})$ and $\mathrm{C}_{30}$ column (50-60\% MeOH)) to obtain hypolaetin 7-O-glucoside (6, $1 \mathrm{mg}, 0.001 \%)$ [12], kaempferol 3-O-(6"-galloyl) glucoside (7, $6 \mathrm{mg}, 0.006 \%)$ [13], quercetin 3-O-(6"-galloyl) glucoside (8, $8 \mathrm{mg}, 0.008 \%)$ [14], quercetin 7-O-glucoside (9, $2 \mathrm{mg}, 0.002 \%)$ [15], quercetin 3-O-glucoside (10, 26 $\mathrm{mg}, 0.026 \%)$ [16] and gossypetin (11, $7 \mathrm{mg}, 0.007 \%)$ [17]. Fr. 3 (1.8 g) was purified by HPLC (ODS column $(60 \% \mathrm{MeOH})$ and $\mathrm{C}_{30}$ column (65$70 \% \mathrm{MeOH})$ ) to obtain junsainoside $\mathrm{A}(\mathbf{1 2}, 32 \mathrm{mg}, 0.032 \%)$, quercetin (13, $62 \mathrm{mg}, 0.062 \%)$ and kaempferol 7-O-(6"-galloyl) glucoside (14, 2 $\mathrm{mg}, 0.002 \%$ ) [18]. The $100 \% \mathrm{MeOH}$ eluent ( $4.65 \mathrm{~g}$ ) was applied to ODS column chromatography ( $100 \mathrm{~g}, 70 \rightarrow 80 \rightarrow 90 \rightarrow 100 \% \mathrm{MeOH})$ to obtain fractions: Fr. 1 (1.62 g), Fr. 2 (0.77 g), Fr. 3 (0.67 g) and Fr. 4 (0.95 g). Fr. $1(1.62 \mathrm{~g})$ was purified by HPLC (ODS column $(70-80 \% \mathrm{MeOH})$ and $\mathrm{C}_{30}$ column (70-80\% $\left.\mathrm{MeOH}\right)$ ) to obtain quercetin (13, $\left.84 \mathrm{mg}, 0.084 \%\right)$ and kaempferol $(15,54 \mathrm{mg}, 0.055 \%)$. A refractive index detector was used for detection of the peak on HPLC purification. Isolated known compounds were identified by comparison of ${ }^{13} \mathrm{C}$ - and ${ }^{1} \mathrm{H}-\mathrm{NMR}$ spectra and mass spectra with reported values or authentic standard samples of 1, 4, 13 and 15 (Figure 1).<smiles>NC(Cc1ccccc1)C(=O)O</smiles>

Phenylalanine (1) $\quad p$-Hydroxybenzoic acid (2)<smiles>O=C(O)c1ccc(O)cc1</smiles><smiles>CCOC(=O)c1cc(O)c(O)c(O)c1</smiles>

Ethyl gallate (3)<smiles>O=c1cc(-c2ccc(O)c(O)c2)oc2c(O)c(OC3OC4OC3C(O)C(O)C4O)cc(O)c12</smiles>

Hypolaetin 7-O-glucoside (6)<smiles>O=c1c(O)c(-c2ccc(O)c(O)c2)oc2c(O)c(O)cc(O)c12</smiles>

Gossypetin (11)

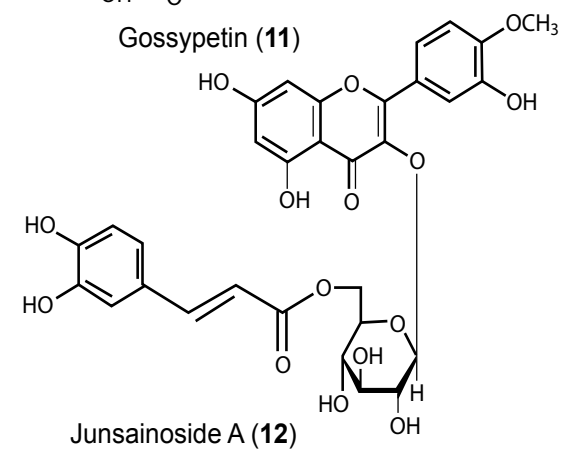

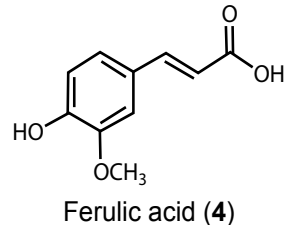

Ferulic acid (4)<smiles>O=C(/C=C/c1ccc(O)c(O)c1)OC1C2OC(O)(OC(CO)C2O)C1O</smiles>

Caffeoyl glucose (5)<smiles>[2H]C(=C)/C=C(\C)c1oc2cc(O)cc(O)c2c(=O)c1OC1OC2OC(C(O)C2O)C1OC(=O)c1cc(O)c(O)c(O)c1</smiles><smiles>COc1c(-c2ccc(O)c(O)c2)oc2cc(O)cc(O)c2c1=O</smiles>

Kaempferol 3-O-(6"-galloyl) glucoside (7): $\mathrm{R}=\mathrm{H}$ Quercetin 3-O-(6"-galloyl) glucoside (8): R=04<smiles>[R]c1cc(-c2oc3cc(O)cc(O)c3c(=O)c2O)ccc1O</smiles>

Kaempferol (15): $\mathrm{R}=\mathrm{H}$ Quercetin (13): $\mathrm{R}=\mathrm{OH}$<smiles>O=C(OCC1OC(Oc2cc(O)c3c(=O)c(O)c(-c4ccc(O)cc4)oc3c2)C(O)C(O)C1O)c1cc(O)c(O)c(O)c1</smiles>

Kaempferol 7-O-(6"-galloyl) glucoside (14)

Figure 1: Constituents isolated from water shield. 
Citation: Shimoda H, Nakamura S, Hitoe S, Terazawa S, Tanaka J, et al. (2014) Anti-Adipogenic Polyphenols of Water Shield Suppress TNF-aInduced Cell Damage and Enhance Expression of HAS2 and HAPB2 in Adiponectin-Treated Dermal Fibroblasts. Nat Prod Chem Res 2: 146. doi:10.4172/2329-6836.1000146

\section{Structural elucidation of junsainoside A (12)}

Junsainoside A (12) was isolated as a pale yellow powder with negative optical rotation $\left([\alpha]_{\mathrm{D}}^{21}-52.0^{\circ}\right.$ in $\left.\mathrm{MeOH}\right)$. The IR spectrum of 12 suggested the presence of hydroxyl $\left(3400 \mathrm{~cm}^{-1}\right), \alpha, \beta$-unsaturated ester $\left(1689 \mathrm{~cm}^{-1}\right), \gamma$-pyrone $\left(1655 \mathrm{~cm}^{-1}\right)$, aromatic ring $(1605,1514$ $\left.\mathrm{cm}^{-1}\right)$ and ether $\left(1016 \mathrm{~cm}^{-1}\right)$. In the positive-ion matrix-assisted laser desorption/ionization (MALDI)-MS of 12, a quasimolecular ion peak was observed at $m / z 663(\mathrm{M}+\mathrm{Na})^{+}$, and high-resolution (HR) MALDIMS analysis of the quasimolecular ion peak revealed the molecular formula of $\mathbf{1 2}$ to be $\mathrm{C}_{31} \mathrm{H}_{28} \mathrm{O}_{15}$. Acid hydrolysis of $\mathbf{1 2}$ with $5 \%$ aqueous $\mathrm{H}_{2} \mathrm{SO}_{4}$-1,4-dioxane yielded $\mathrm{D}$-glucose, which was identified by HPLC of the tolylthiocarbamoyl thiazolidine derivative. To determine the absolute configuration of glucose of $\mathbf{1 2}$, the method reported by Tanaka et al. was used [19]. The ${ }^{1} \mathrm{H}-\mathrm{NMR}\left(\mathrm{CD}_{3} \mathrm{OD}\right)$ and ${ }^{13} \mathrm{C}-\mathrm{NMR}$ spectra of 12, which were assigned by various NMR experiments, showed signals assignable to a tamarixetin part $[\delta 6.07(1 \mathrm{H}, \mathrm{d}, J=2.0 \mathrm{~Hz}, \mathrm{H}-6), 6.25$ $(1 \mathrm{H}, \mathrm{d}, J=2.0 \mathrm{~Hz}, \mathrm{H}-8), 6.80\left(1 \mathrm{H}, \mathrm{d}, J=8.8 \mathrm{~Hz}, \mathrm{H}-5^{\prime}\right), 7.56(1 \mathrm{H}, \mathrm{dd}, J=8.8$, $\left.\left.2.0 \mathrm{~Hz}, \mathrm{H}-6^{\prime}\right), 7.57\left(1 \mathrm{H}, \mathrm{d}, J=2.0 \mathrm{~Hz}, \mathrm{H}-2^{\prime}\right)\right]$, a $\beta$-D-glucopyranosyl moiety $\left[\delta 4.28\left(1 \mathrm{H}, \mathrm{m}, 6 "-\mathrm{H}_{2}\right), 3.35(1 \mathrm{H}, \mathrm{m}, 4-\mathrm{H}), 3.45(1 \mathrm{H}, \mathrm{m}, 5-\mathrm{H})\right.$, $3.43(1 \mathrm{H}, \mathrm{m}, 3-\mathrm{H}), 3.50(1 \mathrm{H}, \mathrm{m}, 2-\mathrm{H}), 5.26(1 \mathrm{H}, \mathrm{d}, J=7.3 \mathrm{~Hz}, 1 "-\mathrm{H})]$, and a $(E)$-caffeoyl group $\left[\delta 6.12\left(1 \mathrm{H}, \mathrm{d}, J=16.0 \mathrm{~Hz}, 8^{\prime \prime \prime}-\mathrm{H}\right), 6.79(1 \mathrm{H}\right.$, d, $J=8.3 \mathrm{~Hz}, 3$ "'-H), $6.91(1 \mathrm{H}, \mathrm{dd}, J=2.0,8.3 \mathrm{~Hz}, 2$ '"-H), $7.04(1 \mathrm{H}, \mathrm{d}$, $\left.\left.J=2.0 \mathrm{~Hz}, 6{ }^{\prime \prime \prime}-\mathrm{H}\right), 7.39\left(1 \mathrm{H}, \mathrm{d}, J=16.0 \mathrm{~Hz}, 7{ }^{\prime \prime}-\mathrm{H}\right)\right]$. The ${ }^{1} \mathrm{H}$ and ${ }^{13} \mathrm{C} \mathrm{NMR}$ spectra of 12 were assigned with the aid of distortionless enhancement by polarization transfer (DEPT), heteronuclear multiple quantum coherence spectroscopy (HMQC) and heteronuclear multiple bond connectivity (HMBC) experiments. The postions of a $(E)$-caffeoyl group and a $\beta$-D-glucopyranosyl moiety were confirmed by HMBC spectroscopy (Figure 2). Namely, long-range correlations were observed between the following proton and carbon pairs: 1 "-H and 3-C; $6 "-\mathrm{H}$ and 9"'-C. Comparison of the ${ }^{13} \mathrm{C}-\mathrm{NMR}$ data for tamarixetin $3-\mathrm{O}-\beta$ -D-glucopyranoside [20] with those for $\mathbf{1 2}$ revealed an acylation shift around the 6 " position. From this evidence, the chemical structure of junsainoside A was determined to be tamarixetin 3-O-(6"-O-Ecaffeoyl)- $\beta$-D-glucopyranoside (12).

Junsainoside A (12): A pale yellow powder, $[\alpha]_{D}{ }^{21}-52.0^{\circ}(c=0.1$, $\mathrm{MeOH})$. HR-MALDI-TOF-MS Calcd for $\mathrm{C}_{31} \mathrm{H}_{28} \mathrm{O}_{15} \mathrm{Na}(\mathrm{M}+\mathrm{Na})^{+}$: 663.1320; Found: 663.1327, UV [MeOH, nm, $(\log \varepsilon)]: 255$ (4.28), 329 (4.32). IR $\left(\mathrm{KBr}, \mathrm{cm}^{-1}\right): 3400,1689,1655,1605,1514$, and 1016. ${ }^{1} \mathrm{H}-\mathrm{NMR}$ $\left(\mathrm{CD}_{3} \mathrm{OD}, 500 \mathrm{MHz}\right) \delta: 3.35(1 \mathrm{H}, \mathrm{m}, 4 "-\mathrm{H}), 3.43(1 \mathrm{H}, \mathrm{m}, 3 "-\mathrm{H}), 3.45$ $\left(1 \mathrm{H}, \mathrm{m}, 5^{\prime \prime}-\mathrm{H}\right), 3.50\left(1 \mathrm{H}, \mathrm{m}, 2^{\prime \prime}-\mathrm{H}\right), 3.88\left(3 \mathrm{H}, \mathrm{s}, 4^{\prime}-\mathrm{OCH}_{3}\right), 4.28(2 \mathrm{H}, \mathrm{m}$, 6"-H), 5.26 (1H, d, J=7.3 Hz, 1"-H), 6.07 (1H, d, J=2.0 Hz, 6-H), 6.12

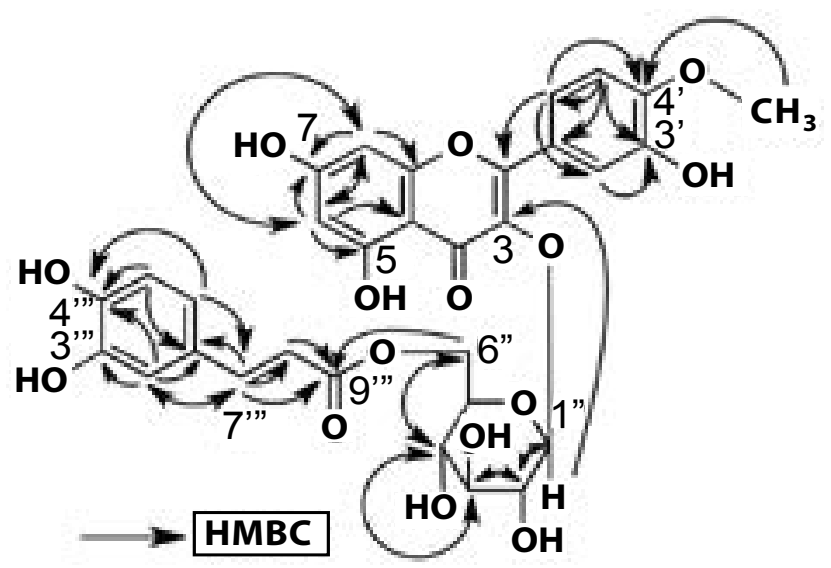

Figure 2: Correlation of HMBC spectrum of junsainoside $A$ (12).
$(1 \mathrm{H}, \mathrm{d}, J=16.0 \mathrm{~Hz}, 8 " '-\mathrm{H}), 6.25(1 \mathrm{H}, \mathrm{d}, J=2.0,8-\mathrm{H}), 6.79(1 \mathrm{H}, \mathrm{d}, J=8.3$ $\mathrm{Hz}, 5$ "'-H), $6.80\left(1 \mathrm{H}, \mathrm{d}, J=8.8 \mathrm{~Hz}, 5^{\prime}-\mathrm{H}\right), 6.91\left(1 \mathrm{H}, \mathrm{dd}, J=8.3,2.0 \mathrm{~Hz}, 6^{\prime \prime}-\right.$ H), $7.04\left(1 \mathrm{H}, \mathrm{d}, J=2.0 \mathrm{~Hz}, 2\right.$ '"-H), $7.39\left(1 \mathrm{H}, \mathrm{d}, J=16.0 \mathrm{~Hz}, 7^{\prime \prime}-\mathrm{H}\right), 7.56$ $\left(1 \mathrm{H}, \mathrm{dd}, J=8.8,2.0 \mathrm{~Hz}, 6{ }^{\prime}-\mathrm{H}\right), 7.57\left(1 \mathrm{H}, \mathrm{d}, J=2.0 \mathrm{~Hz}, 2{ }^{\prime}-\mathrm{H}\right) .{ }^{13} \mathrm{C}-\mathrm{NMR}$ $\left(\mathrm{CD}_{3} \mathrm{OD}, 125 \mathrm{MHz}\right) \delta_{\mathrm{C}}: 159.2$ (C-2), 135.2 (C-3), 179.4 (C-4), 162.9 (C-5), 99.8 (C-6), 165.8 (C-7), 94.7 (C-8), 158.4 (C-9), 105.6 (C-10), 123.1 (C-1'), 123.4 (C-2'), 115.9 (C-3'), 149.8 (C-4'), 115.9 (C-5'), 123.4 (C-6'), 56.5 (4'-OCH $), 103.8$ (Glc-1"), 75.6 (Glc-2"), 78.0 (Glc-3"), 71.8 (Glc-4"), 75.9 (Glc-5"), 64.3 (Glc-6"), 127.6 (C-1"'), 146.8 (C-2"'), 149.3 (C-3"'), 150.5 (C-4"'), 116.4 (C-5"'), 124.2 (C-6"'), 146.8 (C-7"'), 115.0 (C-8"'), 168.8 (C-9"'). Positive-ion MALDI-TOF-MS: $m / z 663(\mathrm{M}+\mathrm{Na})^{+}$ (Figure 2).

\section{Reagents}

Human TNF- $\alpha$ quantkine ELISA kit, human total adiponectin/ Acrp30 quantkine ELISA Kit and recombinant human adiponectin/ Acrp30 were obtained from R\&D Systems (Minneapolis, MN, USA). Recombinant TNF- $\alpha$ was purchased from Life Technologies (MD, USA). Kaempferol 3-O-glucoside and tiliroside were purchased from Extrasynthese (Cedex, France). Radioimmunoprecipitation assay (RIPA) buffer, protease and phosphatase inhibitor cocktail, and Pierce Western Blotting Substrate Plus were purchased from Thermo Fisher Scientific Inc. (Waltham, MA, USA). Goat anti-hyaluronan synthase (HAS) 2 IgG was obtained from Santa Cruz Biotechnology (Dallas, TX, USA). Rabbit anti-hyaluronan binding protein (HABP) 2 IgG was purchased from Abnova (Taipei, Taiwan). Mouse anti- $\beta$-actin (H196) IgG and 3-(4,5-dimethylthiazol-2-yl)-2,5-diphenyltetrazolium bromide (MTT) were purchased from Sigma-Aldrich (St. Louis, MO, USA). Horseradish peroxidase (HRP)-conjugated anti-rabbit IgG, antigoat IgG and anti-mouse IgG were purchased from Millipore (Billerica, MA, USA).

\section{Cells}

3T3-L1 (JCRB9014) and human diploid fibroblasts (TIG-108, JCRB0537) were obtained from the National Institute of Biomedical Innovation (Osaka, Japan). Normal human neonatal fibroblasts (NB1RGB, RCB0222) were obtained from Riken Bio Resources Center (Tsukuba, Japan). Human subcutaneous preadipocyte culture kit (Poietics $^{\mathrm{TM}}$ ) was obtained from Lonza (Basel, Switzerland).

\section{Lipid accumulation in cultured 3T3-L1 and human subcutaneous adipocytes}

3T3-L1 cells $\left(1 \times 10^{4}\right.$ cells $\left./ 200 \mu \mathrm{L}\right)$ suspended in Dulbecco's modified essential medium (D-MEM) containing $10 \%$ fetal calf serum (FCS) were seeded onto a 48-well culture plate and cultured for $24 \mathrm{hr}$. The medium was then changed to a new one containing $10 \% \mathrm{FCS}, 5 \mu \mathrm{g} / \mathrm{mL}$ insulin, $0.25 \mu \mathrm{M}$ dexamethasone and $0.5 \mathrm{mM}$ isobutylmethyl xanthine and the cells were cultured for 2 days to induce differentiation. The medium was then changed to a new one containing 10\% FCS, $5 \mu \mathrm{g} /$ $\mathrm{mL}$ insulin and test sample dissolved in dimethyl sulfoxide (DMSO). The final concentration of DMSO was $0.1 \%$. The medium was changed to a new one every other day and the cells were cultured for a total of 6 days. The cells were stained with oil red $\mathrm{O}$ and observed under a microscope. The dye in cells was dissolved in isopropanol to measure the absorption at $540 \mathrm{~nm}$. For the evaluation of cytotoxicities of the compounds from water shield, MTT assay was performed according to Denizot et al. [21], with modification. Briefly, cells $\left(5 \times 10^{3}\right.$ cells $\left./ 100 \mu \mathrm{L}\right)$ were seeded in a 96-well culture plate and treated by the same procedure as described above. Then MTT reagent was added to each well and the plate was incubated for 2-4 hr. After washing the plate with phosphate buffered saline, pH 7.4 (PBS, Gibco ${ }^{\circledR}$, Life Technologies, CA), the 
Citation: Shimoda H, Nakamura S, Hitoe S, Terazawa S, Tanaka J, et al. (2014) Anti-Adipogenic Polyphenols of Water Shield Suppress TNF-aInduced Cell Damage and Enhance Expression of HAS2 and HAPB2 in Adiponectin-Treated Dermal Fibroblasts. Nat Prod Chem Res 2: 146. doi:10.4172/2329-6836.1000146

Page 4 of 7

formed formazan dye was dissolved in $0.04 \mathrm{M} \mathrm{HCl} /$ isopropanol solvent completely and the absorbance was measured at $570 \mathrm{~nm}$.

Human subcutaneous preadipocytes $\left(2 \times 10^{4}\right.$ cells $\left./ 200 \mu \mathrm{L}\right)$ suspended in the growth medium attached to the kit were seeded onto a 48 -well culture plate and cultured for $24 \mathrm{hr}$. The medium was changed to the differentiation medium containing test sample (final concentration of DMSO: $0.1 \%$ ) for 10 days. The medium was then collected and stored at $-20^{\circ} \mathrm{C}$. The contents of TNF- $\alpha$ and adiponectin were determined using a commercial kit. The cells were stained with oil red $\mathrm{O}$ and absorbance was measured as described above.

\section{Fibroblast damage induced by TNF-a}

NB1RGB cells $\left(5 \times 10^{3}\right.$ cells/100 $\left.\mu \mathrm{L}\right)$ suspended in D-MEM containing $10 \%$ FCS were seeded onto a 96 -well culture plate and cultured for $24 \mathrm{hr}$. Then, sample (final concentration of DMSO: $0.1 \%)$ and TNF- $\boldsymbol{\alpha}(10 \mathrm{ng} / \mathrm{mL})$ were added and cultured for $20 \mathrm{hr}$. The cytotoxicity by TNF- $\boldsymbol{\alpha}$ was evaluated by MTT assay as described above.

\section{Evaluation of HAS2 and HABP2 expression in fibroblasts induced by adiponectin}

TIG-108 cells $\left(1 \times 10^{5}\right.$ cells $\left./ 2 \mathrm{~mL}\right)$ suspended in D-MEM containing $10 \%$ FCS were seeded onto a 6-well culture plate and cultured for $24 \mathrm{hr}$. The medium was changed to D-MEM containing $0.5 \%$ FCS and cultured for $24 \mathrm{hr}$. Then, sample (final concentration of DMSO: $0.1 \%)$ and adiponectin $(1 \mathrm{ng} / \mathrm{mL})$ were added and cultured for $72 \mathrm{hr}$. Cells were collected with $200 \mu \mathrm{L}$ of RIPA buffer containing protease and phosphatase inhibitor cocktail. The protein concentration in the cell lysate was adjusted with RIPA buffer to $0.5 \mathrm{mg} / \mathrm{mL}$. The lysate was mixed with the same volume of Laemmli sample buffer $(62.5 \mathrm{mM}$ Tris-HCl, 2\% SDS, 5\% 2-mercaptoethanol, 25\% glycerol and $0.01 \%$ bromophenol blue) and heated at $95^{\circ} \mathrm{C}$ for $5 \mathrm{~min}$. The sample solution $(15 \mu \mathrm{L})$ was electrophoresed on $10 \%$ SDS gel. Separated protein was then transferred to a polyvinylidene fluoride membrane. The membrane was treated with primary antibodies at the following dilution ratios: antiHAS2 $(1: 1,000)$, anti-HABP2 $(1: 2,000)$ and anti- $\beta$-actin $(1: 10,000)$ for $1 \mathrm{hr}$. HRP-conjugated anti-goat $\operatorname{IgG}(1: 25,000)$ or anti-rabbit IgG (1: $25,000)$ was used as the secondary antibody. Detection was performed using by Pierce Western Blotting Substrate Plus and an imaging system (Image Quant LAS500, GE Health Care, Fairfield, CT, USA).

\section{Statistics}

The results are expressed as means and S.E. Significance of the differences was examined by one-way ANOVA followed by Dunnett's test. Differences of $p<0.05$ were considered significant.

\section{Results}

Effects of WSE and the constituents of water shield on lipid accumulation in 3T3-L1 and human cultured subcutaneous adipocytes

As shown in Figure 3, WSE and its constituents showed no cytotoxicity to 3T3-L1 adipocytes. Figures $4 \mathrm{~A}$ and $4 \mathrm{~B}$ illustrate lipid accumulation in 3T3L1 adipocytes. WSE $(1,10 \mu \mathrm{g} / \mathrm{mL})$ significantly suppressed lipid accumulation in the cells. WSE also suppressed lipid accumulation in human subcutaneous adipocytes (Figures 4C and 4D). We also examined the effect of the constituents of water shield extract on lipid accumulation in both cultured cells. Ethyl gallate (3), caffeoyl glucose (5), hypolaetin 7-O-glucoside (6), junsainoside A (12) and kaempferol (15) significantly suppressed lipid accumulation at $10 \mu \mathrm{M}$ in 3T3-L1 (Table 1). Ethyl gallate (3), 6 and 12 exhibited suppressive activity of more than $50 \%$ at $10 \mu \mathrm{M}$. In human subcutaneous adipocytes, 3 ferulic acid (4), 5, 6, quercetin 3-O-(6"-galloyl) glucoside (8), quercetin 3-O-glucoside (10), junsainoside A (12) and kaempferol suppressed lipid accumulation at $1 \mu \mathrm{M}$. Kaempferol 3-O-(6"-galloyl) glucoside (7) and gossypetin (11) significantly suppressed the accumulation at 10

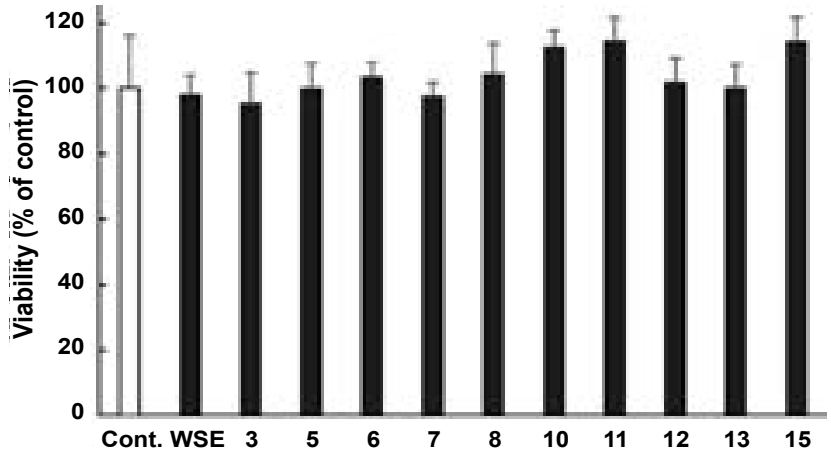

Differentiated 3T3-L1 cells $(5 \times 103$ cells $/ 100 \mu \mathrm{L})$ were cultured with $5 \mu \mathrm{g} / \mathrm{mL}$ insulin and test sample (WSE: $10 \mu \mathrm{g} / \mathrm{mL}$, compounds: $10 \mu \mathrm{M}$ ) for 6 days. Cytotoxicities were evaluated by MTT. Each column represents mean and S.E. $(n=4)$

Figure 3: Cytotoxicity of WSE and its constituents in 3T3-L1 adipocytes.

\begin{tabular}{|c|c|c|c|c|}
\hline & \multicolumn{4}{|c|}{ Inhibition (\%) } \\
\hline & \multicolumn{2}{|c|}{ 3T3-L1 } & \multicolumn{2}{|c|}{ Human Subcutaneous Adipocytes } \\
\hline & $1(\mu \mathrm{M})$ & 10 & $1(\mu \mathrm{M})$ & 10 \\
\hline Ethyl gallate (3) & $63.2 \pm 13.9^{*}$ & $58.9 \pm 14.8^{*}$ & $19.7 \pm 4.7^{\star *}$ & $34.9 \pm 1.9^{* *}$ \\
\hline Ferulic acid (4) & - & - & $23.3 \pm 3.1^{\star *}$ & $48.5 \pm 0.4^{* *}$ \\
\hline Caffeoyl glucose (5) & $42.3 \pm 15.3$ & $43.6 \pm 13.4^{*}$ & $27.5 \pm 1.6^{* *}$ & $35.9 \pm 3.1^{* *}$ \\
\hline Hypolaetin 7-O-glucoside (6) & $52.0 \pm 17.3^{*}$ & $55.8 \pm 14.1^{*}$ & $33.5 \pm 5.4^{* *}$ & $42.5 \pm 1.6^{* *}$ \\
\hline Kaempferol 3-O-(6"-galloyl) glucoside (7) & $25.8 \pm 11.9$ & $34.6 \pm 6.8$ & $13.5 \pm 4.9$ & $25.5 \pm 3.8^{\star *}$ \\
\hline Quercetin 3-O-(6"-galloyl) glucoside (8) & $35.8 \pm 18.5$ & $10.8 \pm 15.2$ & $15.4 \pm 3.7^{*}$ & $21.3 \pm 4.5^{\star *}$ \\
\hline Quercetin 3-O-glucoside (10) & $2.6 \pm 21.6$ & $12.8 \pm 16.6$ & $17.4 \pm 3.9^{*}$ & $22.0 \pm 2.6^{* *}$ \\
\hline Gossypetin (11) & $35.9 \pm 7.6$ & $38.5 \pm 11.3$ & $12.6 \pm 4.3$ & $28.4 \pm 4.3^{* *}$ \\
\hline Junsainoside A (12) & $44.2 \pm 8.0^{* *}$ & $52.8 \pm 9.0^{* *}$ & $36.6 \pm 6.2^{* \star}$ & $45.5 \pm 2.4^{* *}$ \\
\hline Quercetin (13) & $30.7 \pm 17.7$ & $31.1 \pm 1.5$ & - & - \\
\hline Kaempferol (15) & $35.6 \pm 7.5^{\star *}$ & $39.9 \pm 5.6^{* *}$ & $31.4 \pm 4.4^{* *}$ & $40.3 \pm 2.4^{* *}$ \\
\hline
\end{tabular}

Differentiated 3T3-L1 cells $\left(1 \times 10^{4}\right.$ cells/200 $\mu$ L) or subcutaneous preadipocytes $\left(2 \times 10^{4}\right.$ cells/200 $\left.\mu \mathrm{L}\right)$ were cultured with sample for 6 or 10 days. Accumulated lipid was evaluated by oil red $O$ staining. Each value represents mean and the $S . E$. $(n=4)$. Asterisks denote significant differences from the control group at ${ }^{*}: p<0.05$, ${ }^{* *}: p<0.01$. Table 1: Effects of the Constituents Isolated from Water Shield on Lipid Accumulation in Differentiated 3T3-L1 and Human Subcutaneous Adipocytes. 
Citation: Shimoda H, Nakamura S, Hitoe S, Terazawa S, Tanaka J, et al. (2014) Anti-Adipogenic Polyphenols of Water Shield Suppress TNF-aInduced Cell Damage and Enhance Expression of HAS2 and HAPB2 in Adiponectin-Treated Dermal Fibroblasts. Nat Prod Chem Res 2: 146. doi:10.4172/2329-6836.1000146

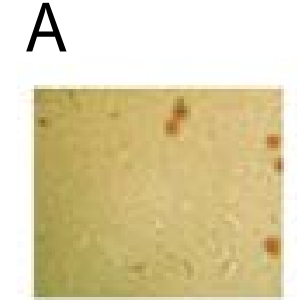

Control

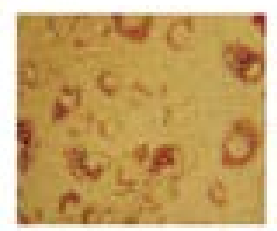

WSE $(1 \mu \mathrm{g} / \mathrm{mL})$

C

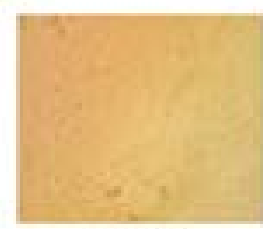

Control

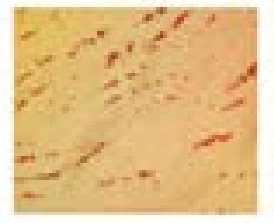

WSE $(1 \mu \mathrm{g} / \mathrm{mL})$

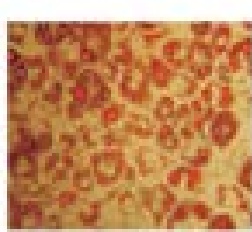

Vehicle

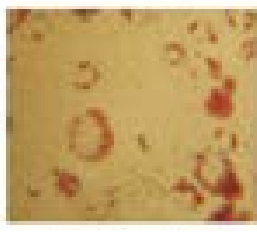

WSE $(10 \mu \mathrm{g} / \mathrm{mL})$

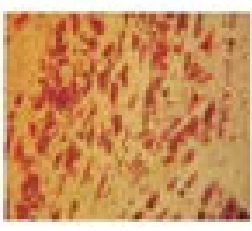

Vehicle

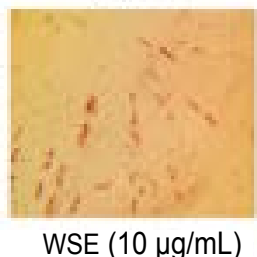

$\mathrm{B}$

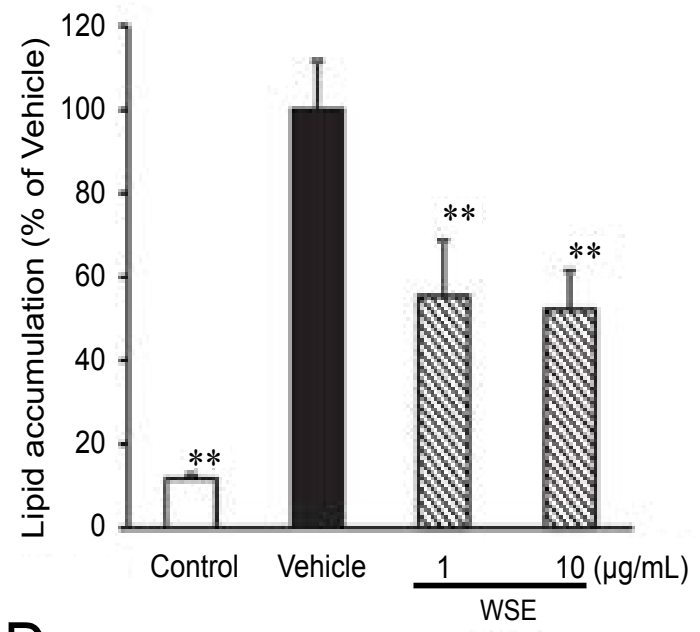

D

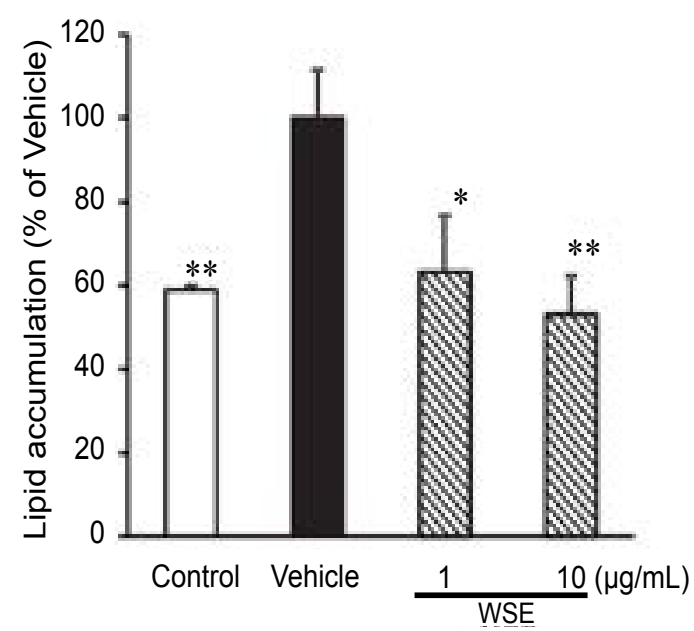

Differentiated 3T3-L1 cells $(1 \times 104$ cells $/ 200 \mu \mathrm{L})$ were cultured with $5 \mu \mathrm{g} / \mathrm{mL}$ insulin and sample for 6 days. The cells were stained with oil red O. Each column represents mean and S.E. $(n=4)$. Control and vehicle refer to differentiated and non-differentiated cells. Asterisks denote significant differences from the control group at ${ }^{*}: p<0.05,{ }^{* *}: p<0.01$

Figure 4: Effects of WSE on lipid accumulation in 3T3-L1 cells (A, B) and human cultured subcutaneous adipocytes (C, D).

$\mu \mathrm{M}$. Among the constituents, 4, 6, 12 and 15 exhibited a suppressive effect of more than $40 \%$ at $10 \mu \mathrm{M}$.

Effects of WSE and the constituents of water shield on TNF- $\alpha$ and adiponectin production from human cultured subcutaneous adipocytes

We evaluated the effect of WSE on TNF- $\boldsymbol{\alpha}$ and adiponectin production from subcutaneous adipocytes. TNF- $\boldsymbol{\alpha}$ production was not suppressed by the treatment of WSE or the constituents (Table 2). On the other hand, WSE did not enhance adiponectin production; however, ethyl gallate (3) and junsainoside A (12) significantly enhanced adiponectin production at $10 \mu \mathrm{M}$.

Effects of WSE and the constituents of water shield on fibroblast damage induced by TNF- $\alpha$

By the treatment of $10 \mathrm{ng} / \mathrm{mL}$ TNF- $\boldsymbol{\alpha}$, the formazan production indicating cell activity was reduced by approximately $41 \%$ compared

\begin{tabular}{|l|c|c|c|c|}
\hline & \multicolumn{3}{|c|}{ Amount of adipocytokine production (\% of control) } \\
\hline & \multicolumn{2}{|c|}{ TNF- $\alpha$} & \multicolumn{2}{c|}{ Adiponectin } \\
\hline WSE & $1(\mu \mathrm{g} / \mathrm{mL})$ & 10 & 1 & 10 \\
\hline & $110.6 \pm 2.2$ & $93.2 \pm 3.0$ & $118.2 \pm 8.9$ & $111.7 \pm 5.1$ \\
\hline Ethyl gallate (3) & $1(\mu \mathrm{M})$ & 10 & 1 & 10 \\
\hline Ferulic acid $(4)$ & $89.9 \pm 5.34$ & $86.7 \pm 4.5$ & $122.2 \pm 5.8$ & $138.3 \pm 10.0^{* *}$ \\
\hline Caffeoyl glucose (5) & $112.0 \pm 10.4$ & $103.6 \pm 2.4$ & $105.7 \pm 5.2$ & $107.6 \pm 3.7$ \\
\hline Hypolaetin & $116.5 \pm 6.1$ & $109.3 \pm 4.7$ & $120.6 \pm 11.3$ & $104.1 \pm 4.1$ \\
\hline 7-O-glucoside (6) & $111.0 \pm 4.9$ & $123.0 \pm 12.1$ & $130.1 \pm 7.9$ & $154.5 \pm 24.7^{*}$ \\
\hline Junsainoside A (12) & $12.8 \pm 6.1$ & $120.6 \pm 8.5$ & $123.3 \pm 7.6$ \\
\hline Kaempferol (15) & $97.0 \pm 3.3$ & $92.7 \pm 3.2$ & - & - \\
\hline
\end{tabular}

Human subcutaneous preadipocytes $\left(2 \times 10^{4}\right.$ cells $\left./ 200 \mu \mathrm{L}\right)$ were differentiated and cultured with sample for 10 days. The contents of TNF- $\alpha$ and adiponectin were determined with an ELISA kit.

Each value represents mean with and S.E. $(n=4)$. Asterisks denote significant differences from the control group at *: $p<0.05,{ }^{* *} p<0.01$.

Table 2: Effects of the Constituents Isolated from Water Shield on TNF- $\alpha$ and Adiponectin Production from Human Subcutaneous Adipocytes. 
Citation: Shimoda H, Nakamura S, Hitoe S, Terazawa S, Tanaka J, et al. (2014) Anti-Adipogenic Polyphenols of Water Shield Suppress TNF-aInduced Cell Damage and Enhance Expression of HAS2 and HAPB2 in Adiponectin-Treated Dermal Fibroblasts. Nat Prod Chem Res 2: 146. doi:10.4172/2329-6836.1000146

Page 6 of 7
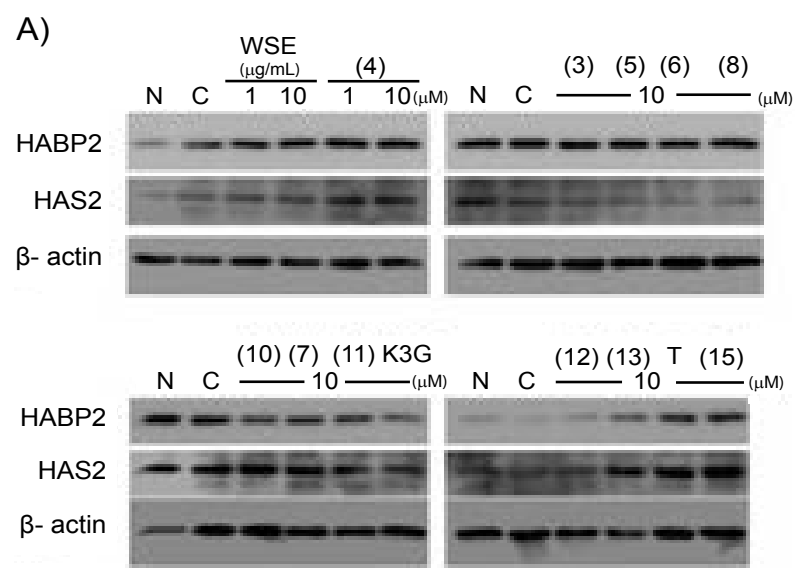

B)

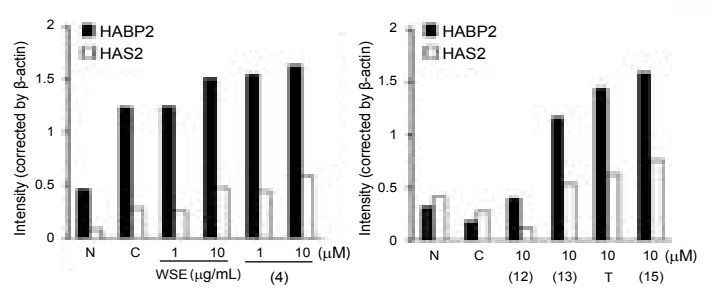

TIG-108 cells $(1 \times 105$ cells $/ 2 \mathrm{~mL})$ in D-MEM containing $0.5 \%$ FCS were cultured with $1 \mathrm{ng} / \mathrm{mL}$ adiponectin and sample for $72 \mathrm{hr}$. Protein expression was evaluated by Western blotting

(A) Western blotting images of fibroblast protein treated with samples. $\mathrm{N}$ : without adiponectin, C: with adiponectin, K3G: kaempferol 3-O-glucoside, T: tiliroside

(B) Relative intensity of HABP2 and HAS2 protein expression corrected using $\beta$-actin

Figure 5: Effects of WSE and its constituents on HABP2 and HAS2 expression in fibroblasts treated with adiponectin.

\begin{tabular}{|l|c|c|}
\hline & \multicolumn{2}{|c|}{ MTT assay (\% of control) } \\
\hline Normal & \multicolumn{2}{|c|}{$141.8 \pm 13.2^{*}$} \\
\hline Control (with TNF-a) & $1(\mu \mathrm{g} / \mathrm{mL})$ & 10 \\
\hline & $133.1 \pm 12.6^{*}$ & $161.6 \pm 11.3^{* *}$ \\
\hline WSE & $1(\mu \mathrm{M})$ & 10 \\
\hline Ethyl gallate (3) & $129.8 \pm 6.0$ & $135.1 \pm 4.6^{*}$ \\
\hline Ferulic acid (4) & $104.9 \pm 8.1$ & $84.3 \pm 5.4$ \\
\hline Caffeoyl glucose (5) & $112.6 \pm 3.3$ & $129.1 \pm 8.6$ \\
\hline Hypolaetin 7-O-glucoside (6) & $120.4 \pm 14.2$ & $98.2 \pm 6.2$ \\
\hline $\begin{array}{l}\text { Kaempferol 3-O-(6"-galloyl)- } \\
\text { glucoside (7) }\end{array}$ & $126.9 \pm 4.5$ & $117.2 \pm 8.2$ \\
\hline $\begin{array}{l}\text { Quercetin 3-O-(6"-galloyl)- } \\
\text { glucoside (8) }\end{array}$ & $106.2 \pm 6.2$ & $110.6 \pm 8.0$ \\
\hline Quercetin 3-O-glucoside (10) & $105.3 \pm 6.2$ & $124.8 \pm 19.5$ \\
\hline Gossypetin (11) & $95.5 \pm 3.7$ & $122.4 \pm 9.7$ \\
\hline Junsainoside A (12) & $97.8 \pm 2.7$ & $92.3 \pm 7.7$ \\
\hline Quercetin (13) & $111.5 \pm 7.1$ & $150.0 \pm 12.6^{*}$ \\
\hline Kaempferol (15) & $74.4 \pm 3.0^{*}$ & $90.1 \pm 2.0$ \\
\hline
\end{tabular}

NB1RGB cells $\left(5 \times 10^{3}\right.$ cells $\left./ 100 \mu \mathrm{L}\right)$ in D-MEM containing $10 \%$ FCS were cultured with sample and $10 \mathrm{mg} / \mathrm{mL}$ TNF- $\alpha$ for $20 \mathrm{hr}$. Cell damage was evaluated by MTT assay.

Each value represents mean and S.E. $(n=6)$. An asterisk denotes significant difference from the control group at ${ }^{*}: p<0.05$

Table 3: Effects of WSE and the Constituents Isolated from Water Shield on Fibroblast Damage Induced by TNF-a.

with that of cells without TNF- $\boldsymbol{\alpha}$. In WSE-treated cells, the cell activity was significantly recovered from cell damage at 1 and $10 \mu \mathrm{g} / \mathrm{mL}$.
Among the constituents of water shield, ethyl gallate (3) and quercetin (13) significantly recovered the cell activity at $10 \mu \mathrm{M}$ (Table 3 ).

\section{Effects of WSE and the constituents of water shield on the expression of HABP2 and HAS2 in fibroblasts treated with adiponectin}

In the fibroblasts cultured with adiponectin, WSE $(10 \mu \mathrm{g} / \mathrm{mL})$ enhanced HABP2 and HAS2 expression (Figure 5). Among the constituents in water shield, ferulic acid (4), quercetin (12) and kaempferol (15) enhanced the expression of HABP2 and HAS2 at 10 $\mu \mathrm{M}$. Glycosides $(\mathbf{3}, \mathbf{5}, \mathbf{6}, \mathbf{7}, \mathbf{8}, \mathbf{1 0}, \mathbf{1 2})$ and gossypetin (11) did not enhance the expression of HABP2 and HAS2. Kaempferol 3-O-glucoside (K3G) used for a reference compound of $\mathbf{1 0}$ also did not enhance HABP2 and HAS2 expression. On the other hand, tiliroside, a reference compound of 12 , enhanced the expression of both.

\section{Discussion}

As a preliminary experiment using subcutaneous adipocytes, we examined the anti-adipogenic effect of test samples in differentiated 3T3-L1 adipocytes. As a result, WSE significantly suppressed lipid accumulation in adipocytes. Among the constituents of water shield, ethyl gallate (3), caffeoyl glucose (5), hypolaetin 7-O-glucoside (6), junsainoside A (12) and kaempferol (15) exhibited suppressive activity at $10 \mu \mathrm{M}$. However, specific similarity in their moieties could not be found to exhibit anti-adipogenic activity. Then, the anti-adipogenic effect of WSE and its constituents was evaluated in subcutaneous adipocytes. WSE and its compounds (3, 5, 6, 12 and 15) suppressed lipid accumulation in differentiated subcutaneous adipocytes at a lower concentration than for 3T3-L1 adipocytes. Moreover, ferulic acid (4), kaempferol 3-O-(6"-galloyl) glucoside (7), quercetin 3-O-(6"-galloyl) glucoside (8), quercetin 3-O-glucoside (10) and gossypetin (11) exhibited anti-adipogenic activity at $10 \mu \mathrm{M}$. These results suggest that WSE suppresses subcutaneous lipid accumulation effectively compared with that of abdominal adipose tissue and many polyphenols in water shield are involved in the activity.

To evaluate the direct effect of WSE on adipocytokine release, we measured TNF- $\alpha$ and adiponectin released from subcutaneous adipocytes. As WSE enhanced neither TNF- $\alpha$ nor adiponectin production, WSE was found not to affect to adipocytokine release directly. In general, adipocytokine production is changed toward lipid accumulation in adipocytes [22]. Thus, WSE is thought to attenuate adipocytokine release indirectly through the suppression of excessive lipid accumulation in adipocytes. However, high concentrations of 3 and 12 enhanced adiponectin release among selected compounds, showing relatively potent anti-adipogenic activity in subcutaneous adipocytes. Regarding naturally occurring compounds with similar chemical structures to $\mathbf{3}$ and $\mathbf{1 2}$, a green tea catechin with a galloyl moiety (epicatechin gallate) has been reported to increase serum adiponectin in hypertensive rats [23]. On the other hand, two compounds with somewhat similar structures to $\mathbf{1 2}$ have been reported to enhance adiponectin production. A citrus polymethoxy flavonoid, nobiletin, enhanced adiponectin secretion from ST-13 adipocytes [24]. Tiliroside, a glycosidic flavonoid with coumaric acid, also enhanced adiponectin production in obese mice [25]. The structure of tiliroside is quite similar to 12. From the activities of these known compounds, $\mathbf{3}$ and $\mathbf{1 2}$ may enhance adiponectin production when applied alone. Galloyl group, methoxyl group in flavonol and cinnamic acid moiety in flavonol glucoside may contribute to the adiponectin release from adipocytes. However, further studies are required to clarify the mechanism of these compounds. 
Citation: Shimoda H, Nakamura S, Hitoe S, Terazawa S, Tanaka J, et al. (2014) Anti-Adipogenic Polyphenols of Water Shield Suppress TNF-aInduced Cell Damage and Enhance Expression of HAS2 and HAPB2 in Adiponectin-Treated Dermal Fibroblasts. Nat Prod Chem Res 2 : 146. doi:10.4172/2329-6836.1000146

Page 7 of 7

Against the TNF- $a$-induced fibroblast damage, WSE, ethyl gallate (3) and quercetin (13) suppressed cell damage. TNF- $\alpha$ is released from not only inflammatory cells but also adipocytes. Besides inflamed skin, normal skin TNF- $\alpha$ level is thought to depend on recruitment from capillaries and adipose tissue, and increase with an increment of dermal adipose tissue. Hence, in addition to the anti-adipogenic effect, WSE and its compounds (3 and 13) are thought to be able to control skin TNF- $\alpha$ level.

In several skin disorders, including scleroderma [26], dermatomyositis [27] and psoriasis [28], dermal adiponectin expression has been reported to be lower than in normal skin. Adiponectin expression is also suppressed by morphological changes of the dermis related to abnormal and excessive lipid accumulation, such as cellulite [29] and type 2 diabetes [30]. Thus, adiponectin expression in dermis and subcutaneous adipose tissue is thought to play a crucial role in maintaining normal skin conditions. Upon the examination of hyaluronan binding protein and its synthase, co-treatment of adiponectin with WSE, ferulic acid (4), quercetin (13) and kaempferol (15) enhanced HABP2 and HAS2 expression. As a preliminary examination, we treated fibroblasts with WSE alone. However, WSE did not enhance the expression of HABP2 and HAS2 (data not shown). Thus, WSE and these compounds are thought probably to enhance hyaluronan production synergistically with adiponectin.

In conclusion, WSE and polyphenolic compounds in water shield were found to suppress lipid accumulation in subcutaneous adipocytes. Ethyl gallate and quercetin are involved in the suppressive effect of WSE on TNF- $\alpha$-induced fibroblast damage. Moreover, ferulic acid, quercetin and kaempferol are found to enhance the expression of HAS2 and HAPB2 with the effect of adiponectin.

\section{Conflict of Interest}

This study was not supported by any other foundation except the Oryza Oil \& Fat Chemical Co. Ltd.

\section{References}

1. Kakuta M, Misaki A (2004) Structual characterization of water-shield mucilage of "Junsai (Brasenia schreberi J. F. Gmel)". Foods Food Ingredients J Jpn 209: 298-303.

2. Legault J, Perron T, Mshvildadze V, Girard-Lalancette K, Perron S, et al. (2011) Antioxidant and anti-inflammatory activities of quercetin 7-O- $\left.\right|^{2}$-Dglucopyranoside from the leaves of Brasenia schreberi. J Med Food 14: 11271134.

3. Takahashi J, Toshima G, Matsumoto Y, Kimura F, Kiuchi T, et al. (2011) In vitro screening for antihyperlipidemic activities in foodstuffs by evaluating lipoprotein profiles secreted from human hepatoma cells. J Nat Med 65: 670-674.

4. Drira R, Chen S, Sakamoto K (2011) Oleuropein and hydroxytyrosol inhibit adipocyte differentiation in 3 T3-L1 cells. Life Sci 89: 708-716.

5. Scazzocchio $B$, Varì R, Filesi C, D'Archivio $M$, Santangelo $C$, et al. (2011) Cyanidin-3-O- $\left.\right|^{2}$-glucoside and protocatechuic acid exert insulin-like effects by upregulating PPAR ${ }^{3}$ activity in human omental adipocytes. Diabetes 60: 22342244 .

6. Wronska A, Kmiec Z (2012) Structural and biochemical characteristics of various white adipose tissue depots. Acta Physiol (Oxf) 205: 194-208.

7. Bhattacharyya S, Dudeja PK, Tobacman JK (2010) Tumor necrosis factor alpha-induced inflammation is increased but apoptosis is inhibited by common food additive carrageenan. J Biol Chem 285: 39511-39522.

8. Ezure T, Amano S (2007) Adiponectin and leptin up-regulate extracellular matrix production by dermal fibroblasts. Biofactors 31: 229-236.

9. Rukachaisirikul T, Khamthong N, Sukpondma Y, Phongpaichit S, HutadilokTowatana N, et al. (2010) Cyclohexene, diketopiperazine, lactone and phenol derivatives from the sea fan-derived fungi Nigrospora sp. PSU-F11 and PSU-F12. Arch Pharm Res 33: 375-380.

10. Takaoka S, Takaoka N, Minoshima Y, Huang JM, Kubo M, et al. (2010) Isolation, synthesis, and neurite outgrowth-promoting activity of illicinin A from the flowers of Illicium anisatum. Tetrahedron 65: 8354-8361.

11. Galland S, Mora N, Abert-Vian M, Rakotomanomana N, Dangles O (2007) Chemical synthesis of hydroxycinnamic acid glucosides and evaluation of their ability to stabilize natural colors via anthocyanin copigmentation. J Agric Food Chem 55: 7573-7579.

12. Siddiqui SA, Sen AB (1971) Hypolaetin 7-glucoside from Juniperus macropoda Phytochemistry 10: 434-435.

13. Collins FW, Bohm BA, Wilkins CK (1975) Flavonol glycosides gallates from Tellima grandiflora. Phytochemistry 14: 1099-1102.

14. Kadota S, Takamori Y, Khin N, Kikuchi T, Tanaka K, et al. (1990) Constituents of the leaves of Woodfordia fruticosa Kurz. I. Isolation, structure, and proton and carbon-13 nuclear magnetic resonance signal assignments of woodfruticosin (woodfordin C), an inhibitor of deoxyribonucleic acid topoisomerase II. Chem Pharm Bull 38: 2687-2697.

15. Li M, Han X, Yu B (2003) Facile synthesis of flavonoid 7-O-glycosides. J Org Chem 68: 6842-6845.

16. Markham KR, Ternal B, Stanley R, Geiger H, Mabry TJ (1978) Carbon-13 NMR studies of flavonoids-III: Naturally occurring flavonoid glycosides and their acylated derivatives. Tetrahedron 34: 1389-1397.

17. Lee S, Park Y, Moon BH, Lee E, Hong S, et al. (2008) Substitution effect of hydroxyl groups on the $1 \mathrm{H}$ and $13 \mathrm{C}$ chemical shifts in hydroxyflavonols. Bull Korean Chem Soc 29: 1597-1600.

18. Barakat HH, Souleman AM, Hussein SAM, Ibrahiem OA, Nawwar MAM (1999) Flavonoid galloyl glucosides from the pods of Acaciafarnesiana. Phytochemistry 51: 139-142.

19. Tanaka T, Nakashima T, Ueda T, Tomii K, Kouno I (2007) Facile discrimination of aldose enantiomers by reversed-phase HPLC. Chem Pharm Bull (Tokyo) 55: 899-901.

20. Fico G, Rodondi G, Flamini G, Passarella D, Tomé F (2007) Comparative phytochemical and morphological analyses of three Italian Primula species. Phytochemistry 68: 1683-1691.

21. Denizot F, Lang R (1986) Rapid colorimetric assay for cell growth and survival. Modifications to the tetrazolium dye procedure giving improved sensitivity and reliability. J Immunol Methods 89: 271-277.

22. Shah A, Mehta N, Reilly MP (2008) Adipose inflammation, insulin resistance, and cardiovascular disease. JPEN J Parenter Enteral Nutr 32: 638-644.

23. Potenza MA, Marasciulo FL, Tarquinio M, Tiravanti E, Colantuono G, et al (2007) EGCG, a green tea polyphenol, improves endothelial function and insulin sensitivity, reduces blood pressure, and protects against myocardial I/R injury in SHR. Am J Physiol Endocrinol Metab 292: E1378-1387.

24. Kunimasa K, Kuranuki S, Matsuura N, Iwasaki N, Ikeda M, et al. (2009) Identification of nobiletin, a polymethoxyflavonoid, as an enhancer of adiponectin secretion. Bioorg Med Chem Lett 19: 2062-2064.

25. Goto T, Teraminami A, Lee JY, Ohyama K, Funakoshi K, et al. (2012) Tiliroside, a glycosidic flavonoid, ameliorates obesity-induced metabolic disorders via activation of adiponectin signaling followed by enhancement of fatty acid oxidation in liver and skeletal muscle in obese-diabetic mice. J Nutr Biochem 23: $768-776$.

26. Arakawa $\mathrm{H}$, Jinnin M, Muchemwa FC, Makino T, Kajihara I, et al. (2011) Adiponectin expression is decreased in the involved skin and sera of diffuse cutaneous scleroderma patients. Exp Dermatol 20: 764-766.

27. Eimer MJ, Brickman WJ, Seshadri R, Ramsey-Goldman R, McPherson DD, et al. (2011) Clinical status and cardiovascular risk profile of adults with a history of juvenile dermatomyositis. J Pediatr 159: 795-801.

28. Gerkowicz A, Pietrzak A, Szepietowski JC, Radej S, Chodorowska G (2012) Biochemical markers of psoriasis as a metabolic disease. Folia Histochem Cytobiol 50: 155-170.

29. Emanuele E, Minoretti P, Altabas K, Gaeta E, Altabas V (2011) Adiponectin expression in subcutaneous adipose tissue is reduced in women with cellulite. Int J Dermatol 50: 412-416.

30. Statnick MA, Beavers LS, Conner LJ, Corominola H, Johnson D, et al. (2000) Decreased expression of apM1 in omental and subcutaneous adipose tissue of humans with type 2 diabetes. Int J Exp Diabetes Res 1: 81-88. 